GASIMOVA F.I., KHANISHOVA M.A., TAGHIYEVA K.R., AZIZOV I.V. $\bowtie$

Institute of Molecular Biology and Biotechnology, Azerbaijan National Academy of Sciences, Azerbaijan, AZ1073, Baku, Matbuat Avenue,2A, e-mail: fazilay@yahoo.com, Ibrahim.azizov47@gmail.com

\ibrahim.azizov47@gmail.com, +994506855093

\title{
EFFECTS OF VARIOUS SALT CONCENTRATIONS ON GERMINATION OF SEEDS AND MORPHOMETRIC PARAMETERS OF DIPLOID WHEAT SEEDLINGS
}

Tolerance to environmental stress factors is an important trait for providing normal vital functions of plant organisms. The investigations revealed several mechanisms by which plants respond to salinity conditions: some mechanisms provide plant tolerance against damaging factors, while others provide reparation of the damage [1]. The formation of the adaptive mechanisms determines plant tolerance to adverse factors. Researches on the plant adaptive mechanisms and their use in purpose of the developing salt-tolerant wheat genotypes are of great importance. One of the methods allowing to overcome the negative effects of salinity is the use of salt-tolerant wheat varieties. Creation of such forms and their cultivation will contribute to enlargement of agricultural areas and decrease in the production loss. The aim of the research was the assessment of salt-tolerance of diploid wheat genotypes at the grain germination stage.

\section{Materials and methods}

Two wheat species Triticum monococcum and Triticum dicoccum were used as the research objects. To determine morphometric parameters (the length of roots and seedlings) of salt tolerance of wheat varieties, seeds were germinated in a $\mathrm{NaCl}$ solution (experimental variant) and in distilled water (control variant) using the roll method [2]. Screening for salt tolerance of wheat genotypes was conducted at 100, 150 and $200 \mathrm{mM}$ concentrations of $\mathrm{NaCl}$. Seeds were kept on wet filter paper, at 20$22^{\circ} \mathrm{C}$ temperature, in the dark for 3 days and then germinated under $12 \mathrm{~h} / 12 \mathrm{~h}$ (light/dark) photoperiod for 7 days. During 10 days the response of wheat seedlings to salt stress, growth dynamics of the above- and underground organs (roots and seedlings) were studied and varieties were compared according to the morphometric parameters. Germination ability for each variant of the wheat geno- types, germination energy on the 3rd and germination persentage on $7^{\text {th }}$ days of the germination phase were determined [3].

\section{Results and discussion}

The studied samples of the experimental variants were found to be characterized by different germination ability. So, germination energy for Tr. monococcum was $85-50 \%$ and for $T r$. dicoccum $85-70 \%$ under salinity. It is known that the general development of the root system is closely related to some plant parameters, which confirm their importance [4]. Therefore, it is expedient to trace dynamics of the development of roots and shoots under stress.In this point of view dynamics of the growth of roots and shoots has been studied at the initial stages of the plant ontogenesis under various salt concentrations. Growth dynamics of the root system of diploid wheat genotypes during 10 days showed that the growth rate declined with increasing salt concentrations, and this decline was different in the genotypes. The Tr. monococcum variety was more sensitive to the influence of salt whereas Tr. dicoccum was tolerant.

Dynamics of the development of diploid wheat roots grown at different salt concentrations during 10 days has been presented in figure $1(\mathrm{a}, \mathrm{b}$, c, d).

Figure 2 (a, b, c, d) shows the growth dynamics of diploid wheat genotypes, germinated under various salt concentration, for 10 days. As seen in the figures dynamics of the development of diploid wheat roots andseedlings at the early stages of ontogenesis showed that all wheat genotypes developed normally in the germination phase and the development rate of seedlings (Fig. 2, a, b, c, d) decreased with increasing salt concentrations, relative to the control. A sharp difference between experimental and control variants was observed on the 3rd day of the germination.

(C) GASIMOVA F.I., KHANISHOVA M.A., TAGHIYEVA K.R., AZIZOV I.V. 

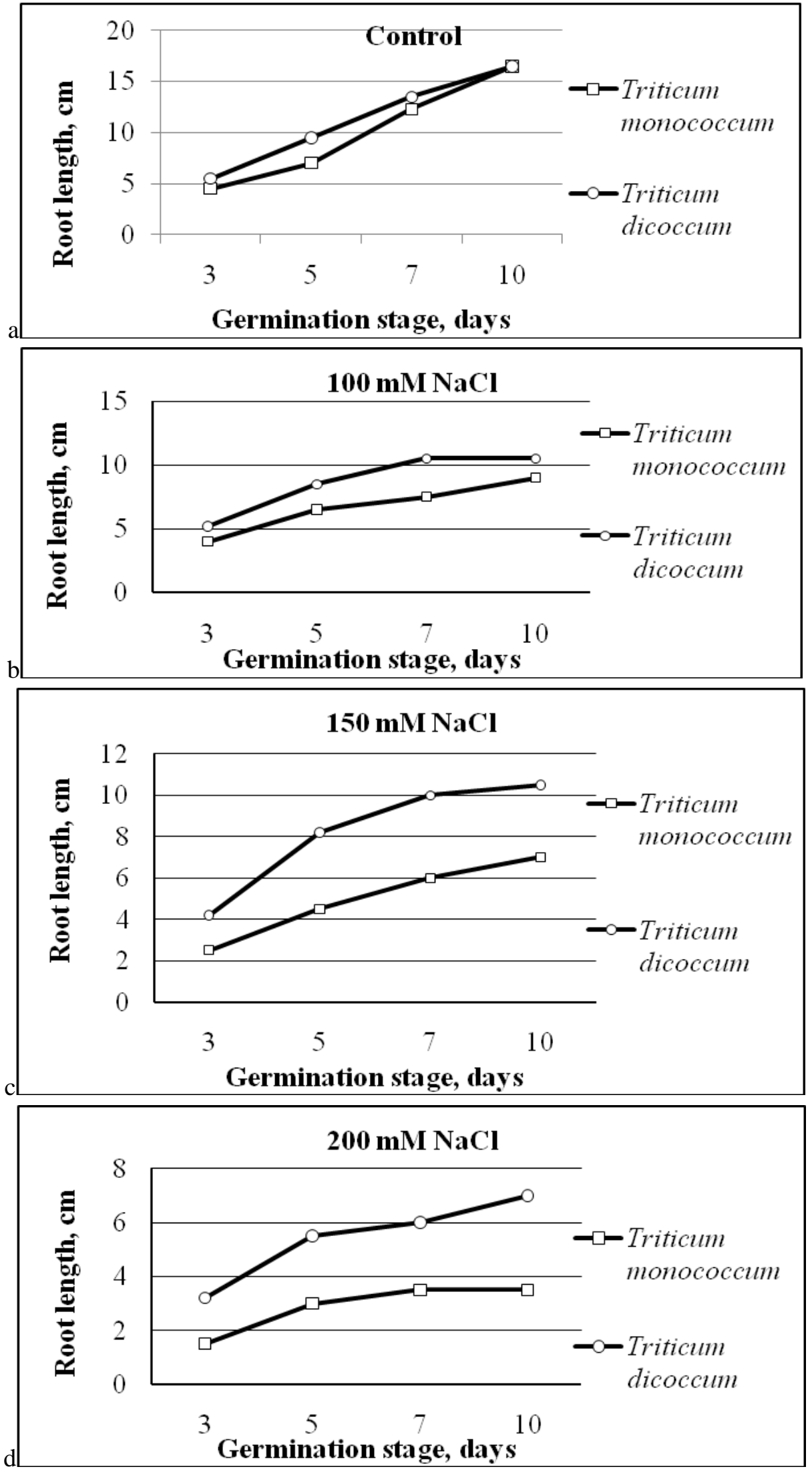

Fig. 1. (a, b, c, d). Dynamics of the growth (development) of roots of diploid wheat genotypes cultivated at different $\mathrm{NaCl}$ concentrations during 10 days. 

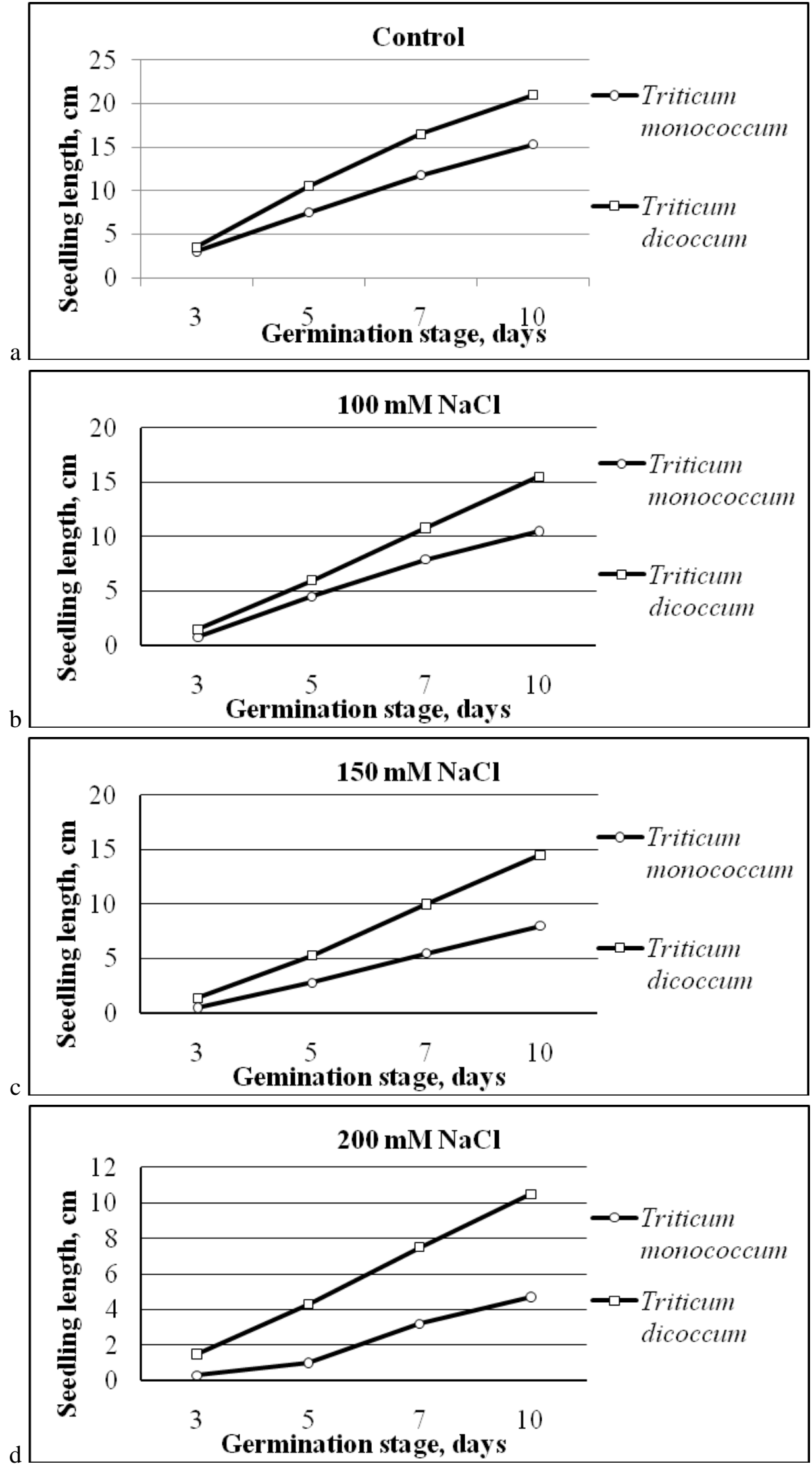

Fig. 2. (a, b, c, d). Dynamics of the growth (development) of seedlings of diploid wheat genotypes cultivated at different $\mathrm{NaCl}$ concentrations during 10 days. 
The Tr. monococcum variety less developed compared with $T r$. dicoccum. However, normal development continued in the both varieties at all salt concentrations.

As seen in the figures the growth of diploid wheat genotype was normal during 10 days of the germination phase and the rate of the development of seedlings decreased with increasing salt concentration. Naturally, after the 3rd day of the germina- tion the pronounced effect of salt was observed compared with control. The Tr.monococcum variety developed weaker than $T r$. dicoccum one, though normal growth continued for both varieties at all concentrations of salt.

Diagrams presented in figure $3(\mathrm{a}, \mathrm{b})$ show parameters (root and seedling lengths) of diploid wheat varieties exposed to various concentrations of $\mathrm{NaCl}$ for 10 days.

Root

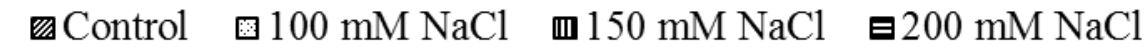
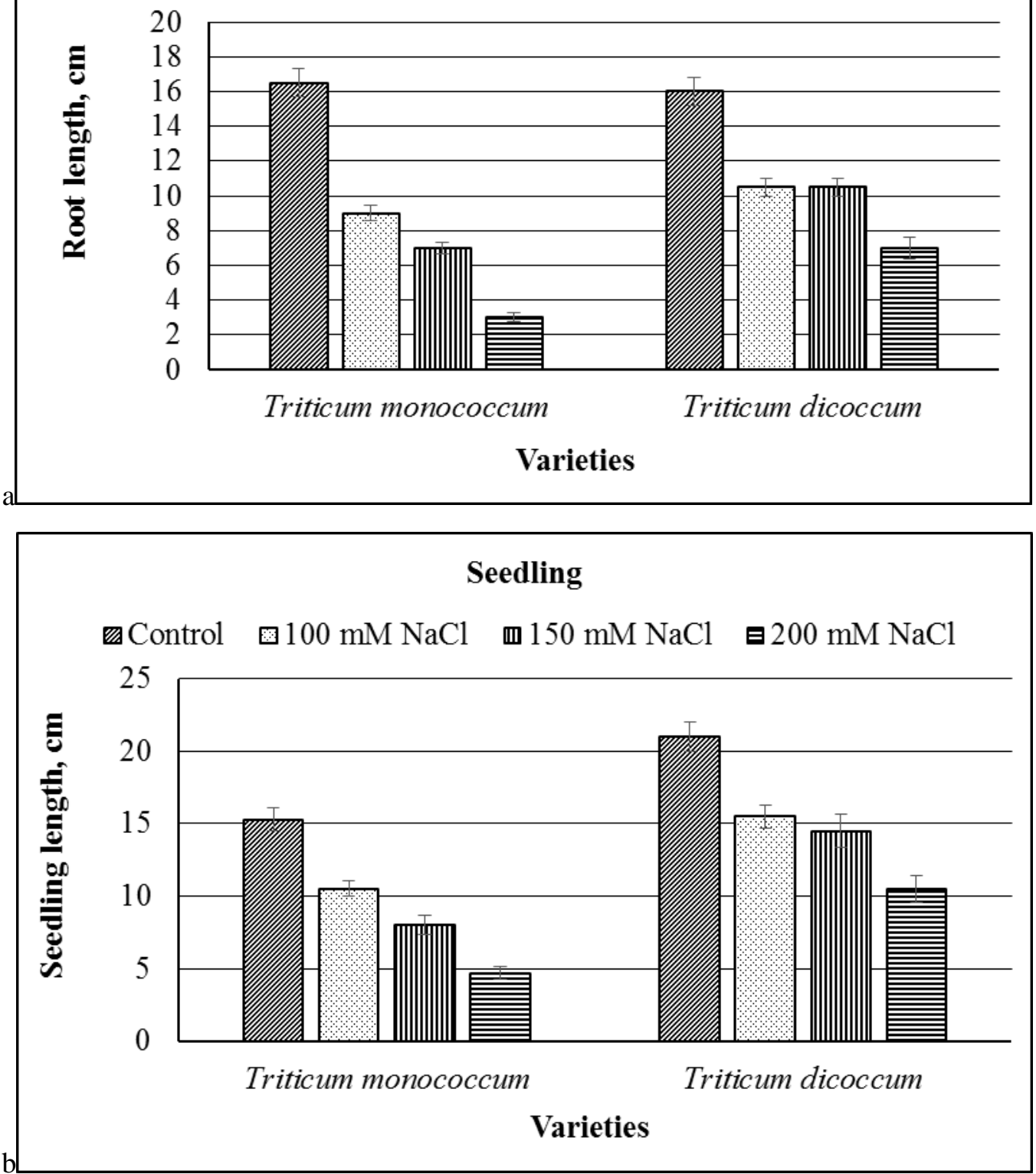

Fig. 3. Average lengths of root hairs (a) and seedlings (b) of 10 day old wheat varieties exposed to various concentrations of $\mathrm{NaCl}$. 
Due to the general plant tolerance, alterations in the linear parameters of the growth processes express salt-tolerance of the varieties more correctly compared with the seed-germination parameters [5]. The retardation in the plant development under adverse envirionment, caused by the suppression of the cell pressure and especially cell tension, may be considered as a plant protective reaction. Tolerant forms faster adapt to stress and restore their development. The study of $\mathrm{NaCl}$ effects on the growth of shoots and roots showed that low salt concentrations stimulate [6, 7], and high concentrations inhibit the growing process. An increase in the accumulation of $\mathrm{K}^{+}$ions was observed in stems and leaves at $25 \mathrm{mM}$ and $50 \mathrm{mM}$ concentrations of $\mathrm{NaCl}$. Triticum aestivium
L. varieties were found to be more sensitive to high salt concentrations compared with Triticum durum Desf ones [8].

According to the morphometric parameters $T r$. dicoccum appeared to be more tolerant to salinity and $T r$. monococcum less tolerant at high salt concentrations compared with the control variants.

\section{Conclusions}

The results suggest that according to the characteristics of salt tolerance of diploid wheat varieties at the germination stage $T r$. monococcum is a sensitive and $T r$. dicoccum, which manifested relatively high parameters, is a tolerant variety.

\section{References}

1. Badridze G., Weidner A., Asch F., Burner A. Variation in salt tolerancewithin a Georgian wheat germplasm collection // Genet. Resour Crop Evol. - 2009. - V. 56. - P. 1125-1130.

2. Удовенко Г.В. Солеустойчивость культурных растений. - Л., 1997. - 185 с.

3. Алиев Р.Т., Аббасов М.А., Рагимли В.Р. Стресс и адаптация растений. - 2014. - 120 с.

4. Белозерова А.А., Боме Н.А. Изучение реакций яровой пшеницы на засоление по изменчивости морфометрических параметров проростков // Ж. Фундаментальные исследования. - 2014. - 12-2. - С. 300-306.

5. Шихмурадов А.З. Устойчивость диплоидных видов пшеницы к повышенному содержанию $\mathrm{NaCl} / /$ Юг России: экология, развитие. - 2011. - 1. - С. 40-43.

6. Ahmed M. El. Naim, Karola F. Mohammed, Elsheikh A. Ibrahim, Nagla A. Suleiman Impact of salinity on seed germination and early seedling growth of three sorghum (Sorghum biolor L. Moench) // Cultivars. Science and Technology. - 2012. - 2. P. 16-20.

7. Wv G-Q., Shui Q-Z. Effect of salinity on seed germination, seedling growth and inorganic and organic solutes accumulation in sunflower (Helianthus annuus L.) // Plant soil Environment. - 2015. - V. 61, № 5. - P. 220-226.

8. Атоев М.Х., Эргашев А., Джумаев Б.Б., Абдуллаев А. Потенциальная интенсивность фотосинтеза и фотосинтетический метаболизм углерода у флаговых листьев сортов пшеницы в условиях хлоридного засоления почвы // Физиология растений. - 2014. - № 3, 187. - С. 39-46.

GASIMOVA F.I., KHANISHOVA M.A., TAGHIYEVA K.R., AZIZOV I.V.

Institute of Molecular Biology and Biotechnology, Azerbaijan National Academy of Sciences, Azerbaijan, AZ1073, Baku, Matbuat Avenue, 2A, e-mail:fazilay@yahoo.com, Ibrahim.azizov47@gmail.com

\section{EFFECTS OF VARIOUS SALT CONCENTRATIONS ON GERMINATION OF SEEDS AND MORPHOMETRIC PARAMETERS OF DIPLOID WHEAT SEEDLINGS}

Aim. The aim of the research was the assessment of salt-tolerance of diploid wheat genotypes Triticum monococcum and Triticum dicoccum at the grain germination stage. Methods. To determine morphometric parameters of salt tolerance of wheat varieties, seeds were germinated in a $\mathrm{NaCl}$ solution and in distilled water using the roll method. Screening for salt tolerance of wheat genotypes was conducted at 100, 150 and $200 \mathrm{mM}$ concentrations of $\mathrm{NaCl}$. Seeds were kept on wet filter paper, at $20-22^{\circ} \mathrm{C}$ temperature, in the dark for 3 days and then germinated under $12 \mathrm{~h} / 12 \mathrm{~h}$ (light/dark) photoperiod for 7 days. Results. Germination energy for $T r$. monococcum was $85-50 \%$ and for $\operatorname{Tr}$. dicoccum 85-70\% under salinity. Growth dynamics of the root system of diploid wheat genotypes during 10 days showed that the growth rate declined with increasing salt concentrations, and this decline was different in the genotypes. Conclusions. The results suggest that according to the characteristics of salt tolerance of diploid wheat varieties at the germination stage $T r$. monococcum is a sensitive and $T r$. dicoccum, which manifested relatively high parameters, is a tolerant variety.

Keywords: wheat genotypes, Triticum monococcum, Triticum dicoccum, salt stress, germination. 